\title{
SIRKULASI KAPILER KAKI PASIEN DIABETES MELLITUS TIPE-2 MELALUI RENDAM KAKI DENGAN MINYAK TANAH GARAM DINGIN DI PUSKESMAS BAITUSSALAM KABUPATEN ACEH BESAR
}

\section{CIRCULATION OF FOOTCAPILER FOR TYPE-2 DIABETES MELLITUS PATIENTS THROUGH SOAKING FOOTS WITH COLD SALT OILIN PUSKESMAS BAITUSSALAM KABUPATEN GREAT ACEH}

\author{
Setio Budi Raharjo ${ }^{1^{*}}$, Amiruddin ${ }^{2}$ \\ ${ }^{1}$ Prodi D-III Keperawatan Banda Aceh ${ }^{2}$ Prodi D-III Keperawatan Meulaboh \\ *e-mail: setio_budiraharjo@yahoo.co.id
}

\begin{abstract}
ABSTRAK
Sirkuasi perifer kaki pasien DM Tipe 2 sangat tergantung pada nilai ankle brachial index $(A B I)$. Untuk mengoptimalkan nilai ABI dalam batas normal, maka peneliti memberikan terapi non farmakalogi. Implementasi non farmakologi ini membantu meningkatkan sirkulasi perifer kaki dan bahan yang digunakan dalam penelitian ini adalah minyak tanah, garam dapur dan es batu. Penelitian menggunakan randomized block design research, terdiri dari 4 perlakuan dengan masing-masing perlakuan pada kelompok: $\mathrm{A}=$ hanya diberi minyak tanah (1 liter) sebagai kelompok kontrol; $\mathrm{B}=$ diberi minyak tanah 1 liter: 500 gram garam: 500 gram es batu; $\mathrm{C}=$ diberi minyak tanah 1 liter: 750 gram garam: 750 gram es batu; dan $\mathrm{D}=$ diberi minyak tanah 1 liter: $1 \mathrm{Kg}$ garam: 1 $\mathrm{Kg}$ es batu. Random sampling dilakukan dengan komputer. Hasil penelitian diperoleh bahwa intervensi rendam kaki minyak tanah garam dingin yang memberikan dampak nyata pada nilai $\mathrm{ABI}$ pasien DM Tipe 2, yaitu perlakuan $\mathrm{C}$ yaitu rendam kaki dengan larutan 1 liter tanah: 750 gram garam: dan 750 gram es batu. Komposisi larutan yang paling berpengaruh terhadap perubahan nilai ABI pasien DM Tipe 2 adalah 1 liter minyak tanah: 750 gram garam: 750 gram es batu. Kesimpulan, penelitian ini telah menunjukkan bahwa sirkulasi perifer kaki pasien DM Tipe 2 dapat ditingkatkan melalui rendam kaki dengan minyak tanah garam dingin.
\end{abstract}

Kata Kunci: sirkulasi, Ankle Brachial Index (ABI), rendam kaki

\begin{abstract}
Circulation of the peripheral feet of patients with Type 2 diabetes is very dependent on the value of the ankle brachial index (ABI). To optimize the ABI value within normal limits, the researchers provided nonpharmacological therapy. This nonpharmacological implementation helps improve the peripheral circulation of the feet and the materials used in this study are kerosene, table salt and ice cubes. The research used randomized block design research, consisting of 4 treatments with each treatment in the group: $A=$ only given kerosene (1 liter) as a control group; $B=$ oiled with 1 liter of soil: 500 grams of salt: 500 grams of ice cubes; $C=$ oiled with 1 liter of soil: 750 grams of salt: 750 grams of ice cubes; and $D=$ oiled with 1 liter of soil: $1 \mathrm{~kg}$ of salt: $1 \mathrm{~kg}$ of ice cubes. Random sampling is done by computer. The results showed that the cold salt kerosene foot soaking intervention had a significant impact on the ABI value of Type 2 $D M$ patients, namely treatment $C$, namely soaking the feet with a solution of 1 liter of soil: 750 grams of salt: and 750 grams of ice cubes. The composition of the solution that most influences changes in the ABI value of Type 2 DM patients is 1 liter of kerosene: 750 grams of salt: 750 grams of ice cubes. Conclusion, this study has shown that the peripheral circulation of the feet of patients with type 2 diabetes can be improved by soaking the feet with cold salt kerosene.
\end{abstract}

Keywords: Circulation, Ankle Brachial Index (ABI), soaking foots 


\section{PENDAHULUAN}

Diabetes Mellitus (DM) merupakan ancaman besar bagi pemerintah dan masyarakat sehingga berbagai upaya pencegahan sangat diperlukan untuk mengurangi angka kematian dan angka kesakitan. Berdasarkan studi epidemiologi terbaru, Indonesia telah memasuki epidemi DM Tipe-2 dengan angka kejadian DM Tipe-2 yang cukup tinggi yaitu pada tahun 2010 mencapai 8,4 juta jiwa dan pada tahun 2030 diperkirakan akan mengalami peningkatan menjadi 21,3 juta jiwa. ${ }^{1,2}$

Tingginya prevalensi Diabetes Mellitus Tipe-2 disebabkan oleh beberapa faktor risiko diataranya faktor risiko yang dapat diubah misalnya kebiasaan merokok, tingkat pendidikan, pekerjaan, aktivitas fisik, kebiasaan merokok, hipertensi, indeks masa tubuh, lingkar pinggang dan umur. ${ }^{3-5}$ Untuk menurunkan angka kesakitan dan komplikasi dari Diabetes Mellitus Tipe-2 maka perlu dilakukan pencegahan tertier seperti modifikasi gaya hidup dan pengobatan. ${ }^{4}$ Perubahan gaya hidup pasien DM Tipe-2 yang dapat dimodifikasi mencakup kualitas hidup dengan perawatan endovaskuler. The Centers for Disease Control and Prevention mengemukakan bahwa perawatan kaki secara teratur dapat mengurangi penyakit kaki diabetik sebesar $50-60 \%$ yang mempengaruhi kualitas hidup. ${ }^{5}$

Unsur utama untuk meningkatkan kualitas hidup pasien DM adalah niat dan kemauan yang tinggi merawat kaki yang dilakukan secara teratur. Beberapa penelitian, menunjukan bahwa pasien DM Tipe-2 dengan atau tanpa komplikasi akan mengalami gangguan mikrovaskuler yang mengakibatkan penurunan sirkulasi kapiler jari kaki dan cenderung mengalami neuropati diabetik setelah 10 tahun menderita diabetes. ${ }^{5,6}$ Gangguan fungsi mikrovaskuler ini ditandai dengan penurunan tegangan oksigen transkutaneous pada kaki dan kelainan larutan natrium-kalium plasma darah akibat hiperglikemia sehingga terjadi pergeseran air dari sel ke extra celluler fluid (ECF) dinamakan efek osmotik glukosa. ${ }^{7,8}$ Gangguan elektrolit plasma darah pada pasien DM Tipe-2 dapat ditanggulangi dengan rendam kaki minyak tanah garam dingin yang berperan sebagai mediator respirasi internal kapiler kaki. Minyak tanah garam dingin merupakan larutan hidrokarbon yang non elekrolit yang memungkinkan lebih cepat terjadinya proses difusi, osmosis, dan filtrasi pada kapiler jaring jari kaki. Perbaikan sirkulasi kapiler kaki pasien DM Tipe-2 dapat ditentukan dengan lancarnya aliran pembuluh darah kapiler bawah kaki dengan mengukur ankle brachial index $(\mathrm{ABI})$, yaitu rasio tekanan darah sistol di lengan atas dengan tekanan darah sistol di ankle kaki bagian bawah. ${ }^{9,10}$

Berdasarkan data dari Dinas Kesehatan Kabupaten Aceh Besar, 
prevalensi DM Tipe 2 pada tahun 2017 adalah sebesar $0,55 \%$ dan prevalensi tertinggi adalah Puskesmas Baitussalam sebesar 7,93\%. Mengacu pada data Dinas Kesehatan Kabupaten Aceh Besar proporsi Diabetes Mellitus Tipe-2 menduduki peringkat ke- 6 dari total penyakit tidak menular di Wilayah Kabupaten Aceh Besar dengan rincian kasus terbanyak penderita Diabetes Mellitus Tipe-2 diderita oleh wanita dengan jumlah 755 kasus sedangkan pada laki-laki 604 kasus. ${ }^{11}$

Berdasarkan data dari Puskesmas Baitussalam, sejak bulan Januari hingga Desember 2017, jumlah penderita DM Tipe2 yang tercatat adalah sebanyak 180 orang. ${ }^{12}$ Hasil wawancara terhadap beberapa penderita DM Tipe-2 diperoleh informasi bahwa sebagian besar dari mereka masih rendah dalam mencapai tujuan pengendalian DM Tipe-2 secara mandiri dikarenakan pengetahuan yang kurang terkait manajemen DM.

Penyakit DM sebagai penyakit tidak menular terbanyak kedua di kecamatan ini memerlukan penanganan yang serius dengan melibatkan keluarga dalam merawat kaki secara mandiri oleh pasien DM Tipe-2. Salah satu upaya non farmakologis yang dapat diterapkan adalah rendam kaki minyak tanah garam dingin.

Terapi kombinasi rendam kaki minyak tanah garam dingin ini diharapkan dapat meningkatnya fungsi vaskulerisasi kapiler kaki yang dilakukan oleh pasien DM Tipe-2 sehingga berdampak pada menjaga kestabilan status kesehatan sesuai dengan tujuan pengendalian DM Tipe-2. ${ }^{13-15}$

Pengendalian DM Tipe-2 diarahkan untuk meningkatkan kualitas hidup pasien dengan menghilangkan keluhan dan tanda DM. Oleh karena lebih dari $75 \%$ pasien DM mempunyai tekanan darah lebih dari 130/80 mmHg, maka gaya hidup sebagai salah satu faktor penyebab DM Tipe-2 yang dapat diubah dengan melakukan perawatan kaki eksternal yang memiliki risiko minimal seperti terapi kombinasi rendam kaki minyak tanah garam dingin. Target terapi kombinasi rendam kaki minyak tanah garam dingin ini untuk menurunkan tekanan darah sistole $<140 \mathrm{mmHg}$.

Selain itu, peneliti lain mengemukakan bahwa sekitar 80\% DM dapat dicegah dengan rajin berolahraga, hindari stres, dan tidak merokok. Adapun tujuan dari penelitian ini adalah mengetahui peningkatan sirkulasi kapiler kaki pasien DM Tipe-2 melalui rendam kaki dengan minyak tanah garam dingin di Wilayah Kerja Puskesmas Kecamatan Baitussalam Kabupaten Aceh Besar Tahun 2018.

\section{METODE}

Penelitian ini dilakukan dengan metode eksperimen dengan Rancangan Acak Kelompok (RAK) yang terdiri dari 4 perlakuan dengan 4 kelompok sebagai 
ulangan. Sebagai pengobatan adalah perbandingan minyak tanah dengan garam dan es balok, yaitu: ${ }^{16,17}$

1. Perlakuan A kontrol / direndam dengan 1 liter minyak tanah

2. Pengobatan B direndam dengan 1 liter minyak tanah, 500 gram garam, 500 gram es batu:

3. Pengobatan $\mathrm{C}$ direndam dengan 1 liter minyak tanah, 750 gram garam, 750 gram es balok:

4. Perlakuan D direndam dengan 1 liter minyak tanah, $1 \mathrm{~kg}$ garam, $1 \mathrm{~kg}$ balok Es.

Perlakuan menunjukkan hasil yang berbeda secara signifikan $(P<0,05)$, tes lebih lanjut dilakukan dan menggunakan Duncan's Multiple Range Test (DRMT). Desain kelompok acak dilakukan dalam upaya untuk mengontrol homogenitas di setiap blok/ kelompok ditandai dengan karakteristik unik termasuk DM Tipe-2, DM Tipe 2 dengan riwayat keluarga, DM Tipe 2 dengan penyakit lama, dan DM Tipe 2 dengan sikap positif. Keempat faktor pengelompokan tidak akan berinteraksi dengan faktor yang diteliti. Metode penelitian ini mempertimbangkan setiap blok dengan menulis nomor intervensi acak, dengan batasan bahwa jumlah pengulangan yang sama tidak boleh terjadi lebih dari satu kali. Nomor intervensi dilakukan dengan bantuan komputer sejumlah acak peserta sesuai dengan jumlah pengulangan. ${ }^{17,18}$
Blok adalah sekelompok unit eksperimen yang diketahui, sebelum percobaan, mirip dengan beberapa variabel dan variabel-variabel ini diharapkan mempengaruhi respon terhadap pengobatan. Dalam desain blok acak, pengacakan perawatan dilakukan secara terpisah di setiap blok. Pengelompokan ini dilakukan untuk mengontrol variabel yang mencapai keadaan homogen meskipun mereka berbeda di setiap blok (variabel ini disebut variabel pemblokiran).

Dalam penelitian ini, variabel yang menghalangi adalah kelompok I (DM Tipe2), kelompok II (DM Tipe-2 riwayat keluarga), kelompok III (DM Tipe-2 rasa nyeri), dan kelompok IV (DM Tipe-2 dengan sikap positif). Sebelum dirawat dengan rendam kaki minyak tanah garam dingin, setiap partisipan/ subjek penelitian diukur tekanan darah brakialis dari sistol lengan kanan atas dan tekanan darah dari sistol dorsal pedis kaki kanan untuk menentukan nilai ABI. Kemudian ini diubah menjadi daftar Indeks ABI. Pengacakan dimulai dengan membagi area menjadi 4 blok. Perlakuan blok secara acak ditugaskan untuk masing-masing kelompok, sehingga setiap perlakuan muncul satu kali dalam setiap kelompok.

Selain itu, setiap perawatan diulangi dalam empat kelompok. Oleh karena itu, unit eksperimen yang terlibat sebanyak 4 unit di setiap blok sehingga total 4 × $4=16$ 
unit eksperimental diperlukan. Selanjutnya, pengacakan pengobatan dilakukan pada masing-masing kelompok dan masingmasing perlakuan hanya muncul satu kali di setiap blok. Pengacakan dilakukan menggunakan bantuan komputer. Hasil perawatan pengacakan adalah sebagai berikut: 1. Bagi unit eksperimen menjadi beberapa kelompok sesuai dengan jumlah pengulangan (4 ulangan); 2. Setiap kelompok dibagi lagi menjadi 4 plot sehingga ada 16 plot (kotak); 3. Pengacakan dilakukan secara terpisah untuk setiap kelompok, karena dalam RAK pengobatan harus muncul sekali dalam setiap pengulangan; 4. Perawatan ditempatkan secara acak ke dalam 16 unit percobaan. Besar sampel penelitian eksperimental ini melalui desain blok acak dengan menggunakan rumus: ${ }^{17,18}$

$$
\begin{gathered}
(\mathrm{t}-1)(\mathrm{r}-1) \geq 15 \\
(4-1)(4-1) \geq 15 \\
(3)(\mathrm{r}-1) \geq 15 \\
(3 \mathrm{r}-3) \geq 15 \\
3 \mathrm{r}) \geq 18 \\
\mathrm{r} \geq 6
\end{gathered}
$$

Di mana: $\quad \mathrm{t}=$ banyak kelompok perlakuan; $r=$ jumlah ulangan

Dengan demikian, besar sampel penelitian ini berjumlah 16 peserta dengan DM Tipe-2 sesuai dengan jumlah ulangan di Wilayah Kerja Puskesmas Baitussalam, Kabupaten Aceh Besar pada tahun 2018. Data hasil observasi disetiap perlakuan diproses secara statistik menggunakan bantuan komputer. Hasil penelitian dengan RBD pada peningkatan sirkulasi kaki pasien DM Tipe-2 melalui rendam kaki dengan minyak tanah garam dingin dapat dilihat dari nilai ABI sebelum dan sesudah serta penambahan nilai $\mathrm{ABI}$.

Larutan minyak tanah (kerosene) sebagai larutan cair dalam penelitian ini telah dilakukan oleh uji klinis PT.Pertamina (PERSERO) pada bulan Juni 2017 Selain itu, penelitian telah dilakukan Persetujuan Etik dengan nomor: LB.02.03 / 3013/2018 pada tanggal 17 Mei 2018.

\section{HASIL}

Dari Tabel.1 dapat dilihat beda nyata rasio komposisi larutan dalam rendam kaki minyak tanah garam dingin. Adapun urutan rasio komposisi larutan yang memberikan beda nyata adalah sebagai berikut perlakuan/ ulangan ketiga, perlakuan/ ulangan pertama, perlakuan/ ulangan kedua, dan perlakuan/ ulangan keempat. Penambahan garam dan es batu dalam minyak tanah menunjukkan bahwa perlakuan/ ulangan ketiga berpengaruh terhadap nilai ABI dibandingkan dengan rasio komposisi larutan lainnya. Data hasil desain kelompok acak dianalisis menggunakan berbagai variabel seperti yang terlihat pada tabel 1 .

Hasil tes ANOVA dua arah yang menunjukkan nilai signifikan, maka dilanjutkan dengan Post Hoc Test. Karena keempat varian populasi adalah sama (nilai probabilitas uji Levene adalah 0,106 di atas 
0,01) maka salah satu asumsi ANOVA telah terpenuhi. Tes ANOVA adalah tes untuk membandingkan rata-rata lebih dari dua kelompok, sedangkan Tes Post Hoc untuk membandingkan antara kelompok.

Setelah nilai F hitung diketahui kemudian dibandingkan dengan $\mathrm{F}$ tabel (yang dapat dilihat pada tabel distribusi $\mathrm{F}$ tabel) pada level real tertentu, dalam hal ini digunakan level real $5 \%$ dan $1 \%$. Jika $\mathrm{F}$ menghitung pengobatan $<\mathrm{F}$ tabel $(\alpha=5 \%)$ berarti perlakuan tidak memiliki efek nyata pada respon yang diamati, yang berarti bahwa Ho diterima pada tingkat nyata $5 \%$. Jika pengobatan yang dihitung $\mathrm{F}>\mathrm{F}$ tabel $(\alpha$
$=5 \%$ ) berarti perlakuan memiliki efek yang signifikan terhadap respons yang diamati, artinya Ho ditolak pada tingkat nyata $5 \%$. Peneliti melanjutkan tes lebih lanjut untuk menentukan perbedaan dalam perawatan antara kelompok menggunakan uji jarak nyata Duncan dapat dilihat pada gambar1.

Pemberian rendam kaki dengan minyak tanah garam dingin dengan perbandingan 1 liter minyak tanah: 750 gram garam; dan 750 gram es batu memberikan perubahan dalam nilai $\mathrm{ABI}$ rata-rata 1,0482 sehingga pengobatan 3 (C) dapat direkomendasikan.

Tabel.1 ANOVA Software mengenai penambahan nilai ABI

\begin{tabular}{cccccc}
\hline Sumber Keragaman & JK & DB & KT & F hit & Sig. \\
\hline Kelompok & 0.441 & 3 & 0.147 & 4.194 & 0.041 \\
Perlakuan & 2.190 & 3 & 0.730 & 20.821 & 0.000 \\
Galat & 0.315 & 9 & 0.035 & & \\
Total & 2,946 & 15 & & & \\
\hline
\end{tabular}

Tabel 2. Perlakuan uji Duncan

\begin{tabular}{cccc}
\hline Ulangan & \multirow{N}{*}{} & $\begin{array}{c}\text { Subset } \\
\mathbf{1}\end{array}$ & $\mathbf{2}$ \\
\hline Ulangan 3 & 4 & -1.04820 & \\
Uangan 1 & 4 & & -1.8591 \\
Ulangan 2 & 4 & & -1.7772 \\
Ulangan 4 & 4 & 1.000 & -7.8510 \\
Sig. & & & .458 \\
\hline
\end{tabular}

Means for groups in homogeneous subsets are displayed.

Based on observed means.

- The error term is Mean Square(Error) =,035. 
Tabel.3 Hasil uji Duncan pengaruh rendam kaki minyak tanah garam dingin terhadap sirkulasi kapiler kaki pasien DM Tipe 2

\begin{tabular}{lccccc}
\hline \multicolumn{1}{c}{ Rasio Larutan } & Rerata & \multicolumn{2}{c}{ Bedanya pada jarak P } & \multicolumn{2}{c}{ BJND } \\
& & $\mathbf{2}$ & $\mathbf{3}$ & $\mathbf{5} \%$ & $\mathbf{1 \%}$ \\
\hline C ( 1:750:750) & -1.0482046 & & & $\mathrm{a}$ & \\
A ( 1 liter) & -1.87897030 & & & $\mathrm{~b}$ & \\
B ( 1:500:500 & -1.77720229 & & $\mathrm{~b}$ & \\
D ( 1:1:1) & 7.85100161 & & & $\mathrm{~b}$ \\
P R(3,9, 0.05) & & 3,20 & 3,34 & & \\
BJND 5 \% & & 0,2993 & 0,31243 & & \\
\hline
\end{tabular}

Rasio komposisi larutan pada perlakuan/ulangan ketiga merupakan media intervensi terbaik berdasarkan rankingnya. Hal tersebut sesuai dengan hasil uji beda nyata Duncan yang dilakukan berdasarkan pada hasil analisis varians sidig ragam yaitu $\mathrm{F}_{\text {hit }}>\mathrm{F}$ tab (20.821> $6,99)$.

\section{PEMBAHASAN}

Berdasarkan analisis statistik, perbandingan rasio komposisi larutan terhadap perubahan nilai ABI memiliki beda nyata pada setiap perbandingan. Pada Gambar.1 dapat dilihat beda nyata rasio komposisi larutan dalam merendam kaki minyak tanah garam dingin dilakukan untuk mengetahui penubahan nilai ABI. Adapun urutan rasio komposisi larutan yang memberikan beda nyata adalah sebagai berikut perlakuan/ ulangan ketiga, perlakuan/ ulangan pertama, perlakuan/ ulangan kedua, dan perlakuan/ ulangan keempat.
Penambahan garam dan es batu dalam minyak tanah menunjukkan bahwa perlakuan/ ulangan ketiga berpengaruh terhadap nilai $\mathrm{ABI}$ dibandingkan dengan rasio komposisi larutan lainnya. Larutan minyak tanah garam dingin dengan berbagai rasio komposisi larutan garam memberikan pengaruh terhadap penambahan nilai $\mathrm{ABI}$. Hal ini disebabkan karena sifat kolinogatif dan kandungan senyawa hidrokarbon dari minyak tanah yang mengakibatkan terjadinya perubahan pada sirkulasi kapiler. Selain itu, minyak tanah bersifat non polar yang memungkinkan terjadinya tarik menarik antara minyak tanah dengan unsur non polar dalam plasma. Dengan alasan ini, larutan minyak tanah dapat mengganti tempat unsur karbon molekul dalam larutan dengan mudah. Sebagai akibatnya semua zat-zat akan larut dalam semua perbandingan. Dengan demikian, senyawa non polar dapat melarutkan zat terlarut non polar dengan tekanan dalam yang 
sama melalui interaksi dipol induksi. ${ }^{18}$ Perbedaan rasio komposisi larutan dalam merendam kaki minyak tanah garam dingin dilakukan untuk mengetahui rasio komposisi larutan yang mampu melarutkan zat terlarut secara maksimal. Garam dan es batu memberikan efek stimulan yang membuat pembuluh darah berkontraksi sehingga aliran darah dan reaksi kimia melambat.

Hal tersebut menghambat radang sedangkan aliran darah menuju kapiler kaki bertambah yang menyebabkan sirkulasi kapiler dapat berfungsi lebih baik. Sedangkan sifat panas dari minyak tanah akan memberi efek relaksasi yang membuat pembuluh darah melebar sehingga dapat menurunkan tekanan darah dan mengurangi kaku pembuluh kapiler kaki. Selanjutnya mampu meningkatkan jumlah oksigen dan nutrisi pada jaringan serta memperbaiki sel yang rusak. Dengan demikian, rendam kaki minyak tanah garam dingin dapat membantu meningkatkan sirkulasi darah dengan memperlebar pembuluh darah. Akibatnya sel dan jaringan memperoleh lebih banyak oksigen sehingga meningkatkan dan memperlancar sirkulasi kapiler kaki serta mampu melepaskan zat racun hasil metabolisme dari pembuluh darah kapiler. ${ }^{18,19}$ Rasio larutan dimaksudkan untuk mengetahui komposisi larutan perbadingan maksimal yang mampu merubah fungsi sirkuasi kapiler. Peneliti lain berpendapat bahwa unsur zat non polar pada minyak tanah akan terikat pada solven non polar, sedangkan unsur zat polar akan terlarut ke dalam solven polar. Komposisi non polar dari konsentrasi 75:25 lebih baik dibandingkan dengan konsentrasi 50:50 karena minyak tanah bersifat non polar. ${ }^{18,21}$

Berdasarkan hasil penelitian diketahui bahwa jenis rasio komposisi larutan yang paling banyak meningkatkan nilai ABI yaitu ulangan 3 dan sedikit meningkatkan nilai ABI yaitu ulangan 1, 2, dan 4. Peningkatan nilai ABI dengan menggunakan ulangan 3 mencapai sekitar $0,299 \pm 0.09693$. Secara statistik melalui uji DMRT dengan taraf signifikansi $1 \%$ menunjukkan bahwa ulangan 3 berbeda nyata terhadap perlakuan lainnya.

Hasil penelitian ini sejalan peneliti lain yang menyatakan bahwa rasio komposisi larutan rendam kaki minyak tanah garam dingin yang bermanfaat dalam meningkatkan sirkulasi kapiler kaki pasien DM dengan perbandingan fraksi non polar dan fraksi polar( 75:25) karena pada suasana tersebut media sudah berada dalam larutan jenuh. ${ }^{19,20}$ Sifat koligatif minyak tanah dapat berinteraksi secara maksimal karena adanya penuruan titik beku dan tekanan osmosis dimana larutan yang terjadi mempunyai tekanan osmosis sehinggga proses difusi dan osmosis dapat berlansung disekitar kapiler kaki. Pada ulangan 3 menunjukkan peningkatan nilai $\mathrm{ABI}$ yang paling tinggi diantara kelompok lainnya. 
Sementara itu, setelah dianalisis uji beda nyata menunjukkan bahwa masingmasing rasio komposisi larutan berpengaruh terhadap nilai ABI. Namun demikian, peneliti perlu menguji perbedaan diantara rata-rata perlakuan. Hal ini dilakukan dengan membandingkan selisih diantara rata-rata perlakuan dengan nilai pembanding yang sesuai. Apabila nilai selisih mutlaknya lebih kecil atau sama dengan nilai pembanding, berarti kedua ratarata tersebut tidak berbeda nyata. Hasil uji Duncan adalah 0,4299 < 4,596 yang berarti tidak ada perbedaan

Dengan demikian, nilai ABI memiliki spesifisitas $83,33-9,0 \%$ dan akurasi yang tinggi $(72,2 \%)$ menunjukkan bahwa seseorang memungkinkan telah mengalami stenosis Selain itu, populasi usia antara 50-73 tahun dengan minimal satu faktor risiko vaskuler seperti diabetes, dan hipertensi, maka nilai ABI dapat digunakan sebagai diagnosis awal untuk PAD. ${ }^{21}$ Nilai ABI terkait dengan hipertensi dimana patogenesis hipertensi pada penderita DM Tipe-2 sangat kompleks, banyak faktor berpengaruh pada peningkatan tekanan darah seperti resistensi insulin, kadar gula darah plasma, dan faktor lain pada sistem otoregulasi pengaturan tekanan darah. ${ }^{22,23}$

\section{KESIMPULAN}

Penelitian ini menunjukkan bahwa untuk meningkatkan sirkulasi kapiler kaki pasien DM tipe-2 bisa melalui rendam kaki dengan minyak tanah garam dingin. Adapun komposisi larutan penelitian ini adalah larutan dengan komposisi yaitu 1 liter minyak tanah; 750 gram garam; 750 gram balok es.

\section{SARAN}

Kepada peneliti lain dapat dilakukan penelitian lanjutan dengan kadar komposisi larutan yang lebih akurat. Selain itu, kegiatan penelitian lanjutan perlu disediakan alat ukur yang cukup (1 paket untuk satu partisipan/ responden/ subyek) serta disediakan tempat yang nyaman dalam pelaksanaan.

\section{UCAPAN TERIMA KASIH}

Penulis mengucapkan terima kasih kepada semua pihak yang berpartisipasi dalam penelitian ini sampai akhir selesai kegiatan penelitian. Selain itu, penulis ucapkan terima kasih kepada Poltekkes Kemenkes Aceh atas dukungan dana dan kesempatan yang diberikan untuk melaksanakan kegiatan penelitian.

\section{KONTRIBUSI PENULIS}

Kontribusi penulis pada artikel ini yaitu SBR sebagai kontribusi utama bertanggungjawab dalam seluruh proses penelitian hingga publikasi. Kontribusi anggota yaitu ARD berkontribusi dalam koresponden dan pembuatan serta finalisasi naskah publikasi. 


\section{DAFTAR PUSTAKA}

1. PERKENI. Konsensus Pengendalian Dan Pencegahan Diabetes Melitus Tipe 2 Di Indonesia 2015.; 2015. doi:10.1017/CBO9781107415324.004

2. Laporan riskesdas Aceh 2018. 2019.

3. Zheng J, Hasting MK, Zhang X, et al. A pilot study of regional perfusion and oxygenation in calf muscles of individuals with diabetes with a noninvasive measure. J Vasc Surg. 2014;59(2):419-426.

doi:10.1016/j.jvs.2013.07.115

4. Kusumaningrum NSD, Asriningati R. Identifikasi risiko diabetc foot ulcer(DFU) pada pasien dengan Diabetet Mellitus. J Luka Indones. 2016;2(1):1-10.

5. Rosyida K. Gambaran neuropati perifer pada diabetis di wilayah kerja puskesmas kedung mundu semarang. 2016:92.

6. Oyer DS, Saxon D, Shah A. Quantitative assessment of diabetic peripheral neuropathy with use of the clanging tuning fork test. Endocr Pract. 2007;13(1):5-10. doi:10.4158/EP.13.1.5

7. Liamis G. Diabetes mellitus and electrolyte disorders. World J Clin Cases. 2014;2(10):488. doi:10.12998/wjcc.v2.i10.488

8. Dafriani putri. Jurnal Medika Saintika. J Kesehat Med Saintika. 2016;8(2):1-8.

9. Faglia E, Caravaggi C, Marchetti R, et al. Screening for peripheral arterial disease by means of the anklebrachial index in newly diagnosed Type 2 diabetic patients. Diabet Med. 2005;22(10):1310-1314.

doi:10.1111/j.14645491.2005.01612.x

10. Irawan H. Hyperbaric Oxygen Therapy as Adjuvant Therapy of Diabetic Foot Terapi Oksigen
Hiperbarik sebagai Terapi Adjuvan Kaki Diabetik. Cdk. 2016;43(10).

11. Badan Pusat Statisik dan Bappeda Aceh. Aceh Dalam Angka 2017. 2017:496.

12. Ramadhan N, Marissa N. Karakteristik penderita diabetes mellitus tipe 2 berdasarkan kadar HbA1c di Puskesmas Jayabaru Kota Banda Aceh. Sel. 2015;2(2). doi:10.22435/sel.v2i2.4637.49-56

13. Velankar DH. Maternal Factors Contributing to Low Birth Weight Babies in an Urban Slum Community of Greater Mumbai. Bombay Hosp J. 2009;51(1):26-35.

14. Reynolds E, Vernon-Feagans L, Bratsch-Hines M, Baker CE. Mothers' and Fathers' Language Input from 6 to 36 Months in Rural Two-Parent-Families: Relations to children's kindergarten achievement. Early Child Res Q. September 2018. doi:10.1016/J.ECRESQ.2018.09.002

15. Sylvain H. Peripheral vascular disease. J Dermatol Nurses Assoc. 2013;5(2):102-104. doi:10.1097/JDN.0b013e318287efc0

16. Armaly Z, Farah J, Jabbour A, et al. Major depressive disorders in chronic hemodialysis patients in Nazareth: identification and assessment. Neuropsychiatr Dis Treat. 2012;8:329-338. doi:10.2147/NDT.S31903

17. Sugiyono. prof. dr. sugiyono, metode penelitian kuantitatif kualitatif dan r\&d. intro ( PDFDrive.com ).pdf. 2017.

18. Greenberg B. for Moore, McCabe , and Craig', $\mathrm{s}$ Introduction to the Practice of Statistics Sixth Edition.

19. Anggraini D, Istianingsih D, Gunawan S. Pengaruh Prosentase Solvent Non Polar dalam Campuran Pelarut terhadap Pemisahan Senyawa Non Polar dari Minyak Nyamplung. $J$ 
Tek Pomits. 2014;3(1):98-101.

20. Palumbo P, Melton III J. Peripheral vascular disease and diabetes. Diabetes Am. 1995:401-408.

21. Berard X, Bodin R, Saucy F, et al. Current management of true aneurysm of the dorsalis pedis artery. Ann Vasc Surg. 2011;25(2):265.e13265.e16.

doi:10.1016/j.avsg.2010.06.010

22. Foundation ID. May 2017 What is the effect of the concentration of a salt solution on its surface tension? Table of Contents. 2017;(May).

23. Ahmed S, Ahmed E, Abdallah MD. Polar \& Non Polar Capacitors Effect on Photovoltaic. 2016;01(02):85-87. 